\title{
Unusual Sydney dust storm and its mineralogical and organic characteristics
}

\author{
Rupak Aryal, ${ }^{\mathrm{A}, \mathrm{E}}$ Dheeraj Kandel, ${ }^{\mathrm{B}}$ Durga Acharya, ${ }^{\mathrm{C}}$ Meng Nan Chong ${ }^{\mathrm{D}}$ \\ and Simon Beecham ${ }^{\mathrm{A}}$ \\ A School of Natural and Built Environments, University of South Australia, Mawson Lakes \\ Campus, SA 5095, Australia. \\ ${ }^{B}$ Melbourne School of Engineering, The University of Melbourne, Parkville, Vic. 3010, Australia. \\ ${ }^{\mathrm{C}}$ CSIRO Materials Science and Engineering, lan Wark Laboratories, Clayton, Vic. 3168, Australia. \\ ${ }^{D}$ School of Engineering, Monash University, Jalan Lagoon Selatan, Bandar Sunway Selangor \\ DE 46150, Malaysia. \\ ${ }^{\mathrm{E}}$ Corresponding author. Email: rupak.aryal@unisa.edu.au
}

\begin{abstract}
Environmental context. In 2009, at the end of the longest drought period ever recorded in Australia, a major dust storm blanketed the cities of Sydney and Brisbane for more than $24 \mathrm{~h}$. The source of the dust was inner New South Wales and South Australia, where large scale open-cut mining occurs together with agricultural practices. We report results of extensive mineralogical and chemical analyses of the dust, and discuss their significance in terms of the dust origins and potential human health risks.
\end{abstract}

\begin{abstract}
In a 24-h period from 23 to 24 September 2009, a dust storm passed over Sydney, Australia that produced a red sky and reduced the visibility to a few metres. It was Sydney's worst dust storm since 1942. During this period, the $\mathrm{PM}_{10}$ (particles measuring $10 \mu \mathrm{m}$ or less) value jumped from 50 to $11800 \mu \mathrm{g} \mathrm{m}^{-3}$. The dust storm was sampled and its mineralogical and organic contents were analysed. Four major particle sizes $(0.6,4.5,9.3$ and $20 \mu \mathrm{m})$ were observed in the dust. A multimodal particle distribution indicated a long range of dust transport. Mineralogical analysis showed that the particles were mainly composed of crustal elemental oxides of $\mathrm{Al}$ and $\mathrm{Si}$. The ratio of $\mathrm{Al} / \mathrm{Si}$ was 0.39 and the organic content was $10.6 \%$, which was found to be enriched with humic-type substances. The high $\mathrm{Al} / \mathrm{Si}$ ratio $(>0.3)$ indicated that the dust originated from desert land whereas the high organic content indicated that the particles were also derived from eroded agricultural land. A fluorescence spectroscopic study on the organic matter at excitation and emission wavelengths of 245-265 and 330-350 nm indicated that biohazardous substances were unlikely to be present in the dust.
\end{abstract}

Additional keywords: mineralogical content, organic substances, particle size distribution.

Received 30 August 2012, accepted 30 October 2012, published online 20 December 2012

\section{Introduction}

Many cities frequently face unusual dust storms travelling from a long distance. Examples include yellow sand dust storms in Asia, as well as Sahara dust storms in Northern Europe. ${ }^{[1-3]}$

The composition of atmospheric particulate matter (PM) has become a great concern due to its potential short and long-term human health and environmental impacts. Earlier epidemiological studies have shown that increased levels of ambient PM are associated with increased lung inflammation, cardiopulmonary morbidity and mortality. ${ }^{[4-7]}$ Dust storms carry tonnes of top soil from agricultural land and affects the soil resource base and crop productivity on a long-term basis by damaging plant tissue, causing delay in plant development ${ }^{[8-10]}$ and accelerates land degradation. ${ }^{[11,12]}$ Moreover, the deposition of dust on irrigation canals and rivers affects the water quality of streams, lakes and oceans. ${ }^{[13-17]}$ A study by Lim et al. ${ }^{[18]}$ highlighted the contribution of dust events to the distribution of microbes in the environment from two dust storms in Australia.

For the last few decades, Australia has also been facing frequent dust storms and the latest one was during the period of
22 to 24 September 2009. During this period, many east-coast Australian cities were covered with dust clouds travelling from inner New South Wales (NSW) to Sydney and later to Brisbane. The dust storm hit Sydney on 22 September in the morning and by the afternoon, the dust cloud slowly headed northwards, towards Brisbane, Queensland. It was believed that gale force winds snatched up tonnes of top soil from drought affected areas in western NSW and the eastern part of the Lake Eyre Basin, before travelling hundreds of kilometres eastward. It was reported that during the Sydney dust storm $\sim 75000 \mathrm{t}$ of dust per hour was lost off the NSW coast, north of Sydney. ${ }^{[19]}$ The storm caused economic damage in many cities due to lost productivity and clean-up work afterwards. Tozer ${ }^{[20]}$ estimated that the cost to the NSW economy was in the range of AU\$419 million-\$438 million due to this dust storm.

This dust storm was the most severe since 1942. Fig. 1 shows the iconic Sydney Harbour Bridge before and during the dust storm. During this period, the $\mathrm{PM}_{10}$ (particles measuring $10 \mu \mathrm{m}$ or less) values exceeded the threshold limit by several hundred fold. During the storm period, a massive dust load hovered in the 

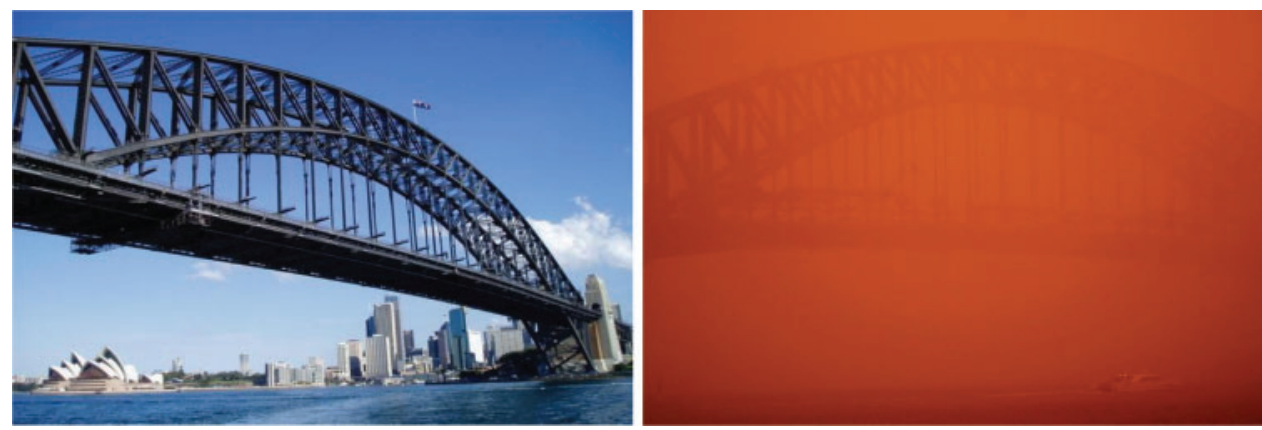

Fig. 1. Photographs of before and during the 2009 Sydney dust storm.
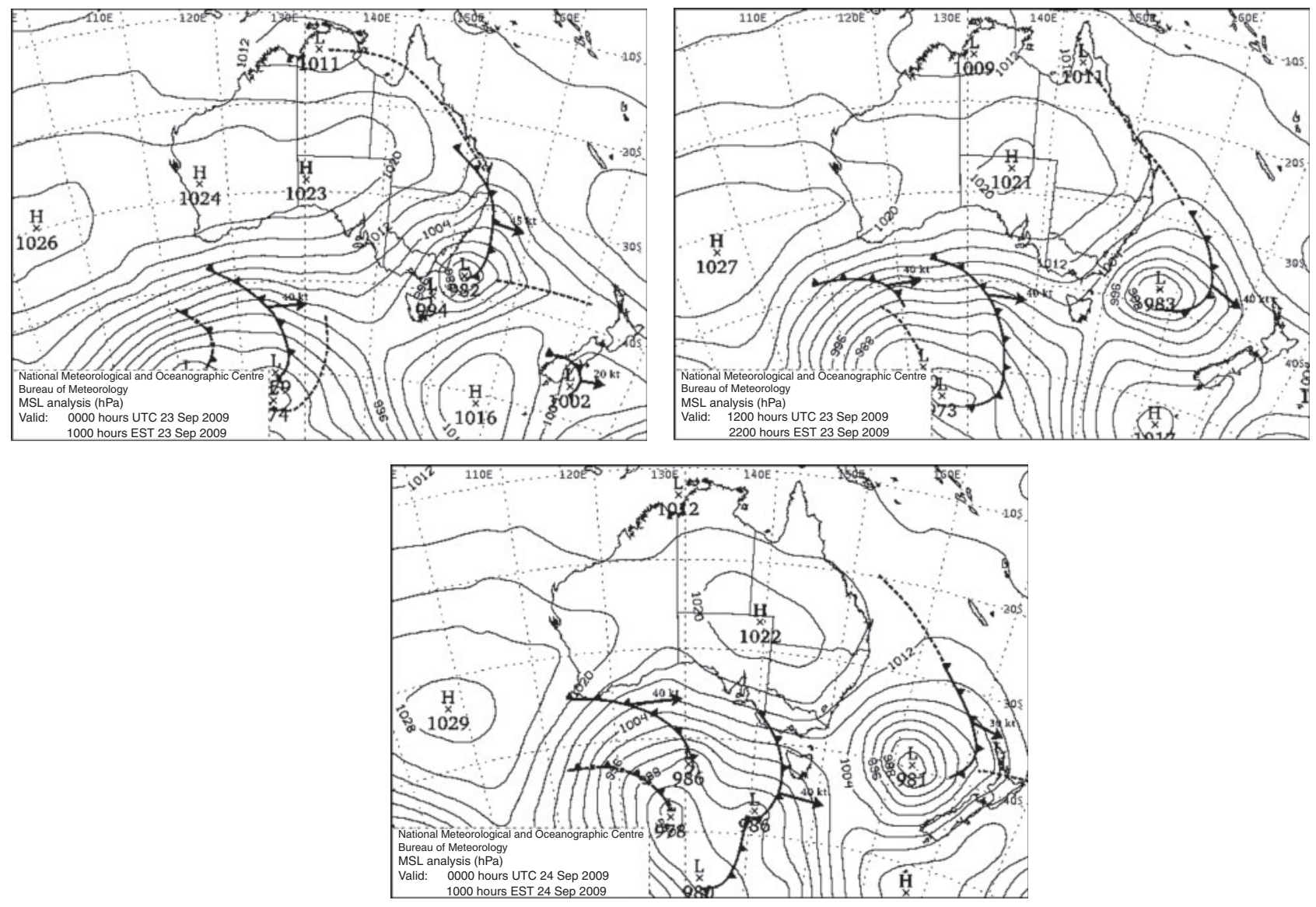

Fig. 2. Synoptic weather conditions associated with dust storm development in Sydney on 23-24 September 2009.

sky and deposited on the catchment surface. Visibility was reduced to $1 \mathrm{~km}$ and the $24-\mathrm{h}$ total suspended solids concentration jumped to over $1500 \mu \mathrm{g} \mathrm{m}^{-3}$. This value is several times higher than the United States Environmental Protection Agency (US EPA) 24-h $\mathrm{PM}_{10}$ standard of $150 \mu \mathrm{g} \mathrm{m}^{-3}$ and $\mathrm{PM}_{2.5}$ (particles measuring $2.5 \mu \mathrm{m}$ or less) standard of $15 \mu \mathrm{g} \mathrm{m}^{-3}$. [21]

The dust storm was associated with a deep low pressure system of 980-990 hPa and a cold front that produced winds over east and south-eastern Australia in the Sydney region on 23 September 2009. With the movement of wind eastward, it pushed the dust cloud both eastwards and southwards. Fig. 2 shows the synoptic weather conditions for 23 September $(0000$ and 1200 hours) and 24 September (0000 hours). This indicates that cyclonic circulation in the eastern sea may have acted as a driving force for the dust storm to move eastward. The average 24-h wind speed on 23 September 2009 was $11 \mathrm{~m} \mathrm{~s}^{-1}$.

The dust particulate is important for its morphology and inorganic and organic contents due to potential human health and environmental impacts. Understanding the overall chemistry of dust particles is not possible by a single analytical method. Thus, it is important to combine and compare results obtained through different analytical methods to achieve a better understanding of the dust storm that had travelled for a long distance before hitting Sydney. The aim of the study was to study the particle sizes, mineralogical content and organic matter associated with this dust storm. For the analysis of particle sizes and the mineralogical composition, a particle size analyser, a differential thermal analyser, a thermogravimetric analyser and 
scanning electron microscopy coupled with energy dispersive X-ray diffraction spectroscopy (SEM-EDX) were used. For organic matter analysis, Fourier-transform infrared spectroscopy (FTIR), fluorescence spectroscopy and size exclusion chromatography were used.

\section{Materials and methods}

\section{Sample collection}

The dust storm sample was collected in the south of Sydney (10 km from Sydney airport, NSW) using a borosilicate glass disc. The collected sample was dried in a dessicator for $48 \mathrm{~h}$ at room temperature and kept refrigerated for further analysis.

\section{Particle size distribution analysis}

The dried dust sample was mixed with Milli-Q water and then subjected to sonification for $10 \mathrm{~min}$ to avoid any aggregation of particles. The particle size distribution of the liquor was measured by a laser particle size analyser (MALVERN SB.0B, UK). The instrument was calibrated using glass beads of $63 \mu \mathrm{m}$ (ATA Scientific, Australia) and was found to be within the standard limits.

\section{Surface morphology and elemental composition analysis}

Scanning electron microscopy (SEM, Environmental Scanning Electron Microscope) equipped with an electron diffraction X-ray (Siemens D5000 X-ray Diffractometer, Germany) was used to obtain particle images and the mineralogical content of the dust. This was done by applying backscattered electron (BSE) imagery with an accelerating voltage of $20 \mathrm{kV}$ and a beam current of $80 \mu \mathrm{A}$. BSE is better for detecting mineral particulates because of its higher atomic number contrast. ${ }^{[22]}$

Wide-angle X-ray scattering (WAXS) measurement of a clay sample was carried out at the Small and Wide angle scattering beam line of the Australian Synchrotron. A loosely packed sample taken into a flat pellet of $\sim 1-\mathrm{mm}$ thickness was exposed to a $12-\mathrm{KeV}$ monochromatic X-ray beam $(\lambda=1.54 \AA)$ for $10 \mathrm{~s}$ at room temperature. The scattering pattern at wide angles was recorded using a Pilatus detector at different goniometer angles and the complete scattering data were obtained by combining each dataset obtained at increasing goniometer angles with some overlap of angles and scaling the intensity of each pattern to ensure an excellent overlap pattern.

\section{Organic analysis \\ Thermogravimetric analysis}

Thermogravimetric analysis (SETARAM Setsys 16/18, France) and differential scanning calorimetry (TA Instruments DSC 2920, USA) were used to estimate the organic contents and the calorific values of the sampled dust. Nitrogen was used as a dynamic atmosphere (flow rate $=20 \mathrm{~cm}^{3} \mathrm{~min}^{-1}$ ) and platinum pans were used. Temperature and enthalpy calibrations were undertaken using recommended differential thermal analysis (DTA) standards. The dust sample was heated at a rate of $10{ }^{\circ} \mathrm{C} \min ^{-1}$ to $900{ }^{\circ} \mathrm{C}$. The sample was also tested by an ignition loss method. ${ }^{[23]}$

\section{FTIR analysis}

The functional group composition in the storm dust samples was analysed using a FTIR spectrometer with detector (Perkin Elmer Spectrum 2000, USA). FTIR spectra were collected in absorbance mode at wave numbers between 400 and $4000 \mathrm{~cm}^{-1}$ with a resolution of $1 \mathrm{~cm}^{-1}$.

\section{Fluorescence analysis}

Approximately $1 \mathrm{~g}$ of dust sample was mixed with $25 \mathrm{~mL}$ of $0.1-\mathrm{M}$ sodium hydroxide and shaken using an end-over-end shaker for $12 \mathrm{~h}$ at $120 \mathrm{rpm}$. The extract was then filtered through a $0.45-\mu \mathrm{m}$ filter. The filtrate was analysed using fluorescence spectrometry. The excitation emission spectra was obtained using a spectrofluorometer (Varian Cary Eclipse Fluorescence Spectrophotometer, USA) with a wavelength range of 200 to $500 \mathrm{~nm}$ by increasing the wavelength by $5 \mathrm{~nm}$ for excitation and 280 to $500 \mathrm{~nm}$ by increasing the wavelength by $2 \mathrm{~nm}$ for emission. All slit widths were set to $5 \mathrm{~nm}$. The excitation emission value of blank (Milli-Q) data was subtracted from the extract for blank correction.

\section{Molecular weight distribution (MWD) analysis}

The sodium hydroxide extract (filtrate) was used for determining the MWD of organic matter. The extract was subjected to high pressure size exclusion chromatography (HPSEC, Shimadzu Corp., Japan) with a size exclusion column (Protein-pak 125, Waters, Milford, MA). Milli-Q water with phosphate $(\mathrm{pH} 6.8)$ and $\mathrm{NaCl}(0.1 \mathrm{M})$ was used as eluent. The eluent flow rate was $0.75 \mathrm{~mL} \mathrm{~min}^{-1}$. A UV detector $(254 \mathrm{~nm})$ and fluorescence detector (Ex: $250 \mathrm{~nm}, \mathrm{Em}: 340 \mathrm{~nm}$ ) were used to interpret organic substances present in the dust. Standards of molecular weight of various polystyrene sulfonates (PSS: 210, $1800,4600,8000$ and $18000 \mathrm{Da}$ ) were used to calibrate the equipment.

\section{Results and discussion}

Knowledge of the size of dust particles is vital in understanding the effects of dust on human health. It is well documented that increased exposure to thoracic PM is associated with various adverse health effects, such as respiratory diseases, cardiovascular mortality, morbidity and probably, malignant lung diseases. ${ }^{[24-27]}$ Ambient $\mathrm{PM}_{10}$ represents a complex mixture of anthropogenic and naturally occurring airborne particles. ${ }^{[28,29]}$

Fig. 3 shows the $\mathrm{PM}_{10}$ behaviour in Sydney before and after the dust storm on 23 September 2009. Usual PM $_{10}$ in Sydney ranges between $10-110 \mu \mathrm{g} \mathrm{m}^{-3}$. Before the storm the $\mathrm{PM}_{10}$ was below $50 \mu \mathrm{g} \mathrm{m}^{-3}$. During the storm period, the value jumped to $11800 \mu \mathrm{g} \mathrm{m}^{-3}$ and then sharply dropped to $60 \mu \mathrm{g} \mathrm{m}^{-3}$ within $24 \mathrm{~h}$. The contour diagram in Fig. 3 shows how the concentration of the dust particles hovered in the sky in the NSW region during the storm period. According to the NSW Bureau of Health Information, ${ }^{[30]}$ the dust did not show acute effects on human health. However, the economic analysis showed it had huge environmental and economic effects on the city. It was estimated that total soil loss from the storm was over $2000000 \mathrm{t}^{[31]}$ The dust affected land and air transport, construction and retail service sectors and cost over AU\$43 million whereas the overall loss was estimated as between AU\$418 million and $\$ 438$ million. ${ }^{[20]}$

\section{Particle size distribution}

Particle size (or aerodynamic diameter) is often used to characterise PM as it is associated with the origin of the particles and their transport in the atmosphere. Previous studies on urban aerosols have often shown a bimodal distribution in particle size. ${ }^{[32-34]}$

Fig. 4 shows the PM size distribution and cumulative size distribution of particles sampled during the dust storm. The 
particle sizes display several modal distributions. Four major peaks appear at $0.6,4.5,9.3$ and $20 \mu \mathrm{m}$. This multimodal distribution in atmospheric PM indicates that the sampled dust particles were different to normal urban (anthropogenic) dust. $^{[32-35]}$ Out of the total PM, more than $50 \%$ of the particles were less than $10 \mu \mathrm{m}$ in size indicating potential human health hazards. This result is supported by reported real time monitoring data. ${ }^{[36]}$ Knight et al. ${ }^{[37]}$ estimated the expected distance travelled by the particles of various sizes using box models. Table 1 shows the expected distance travelled by particles of different diameter. ${ }^{[37]}$ According to the comparison, the finer particles (less than $6 \mu \mathrm{m}$ ) in the dust may have travelled a long distance $(>1000 \mathrm{~km})$ before reaching Sydney. This result suggested that the storm may have picked up the particles along the

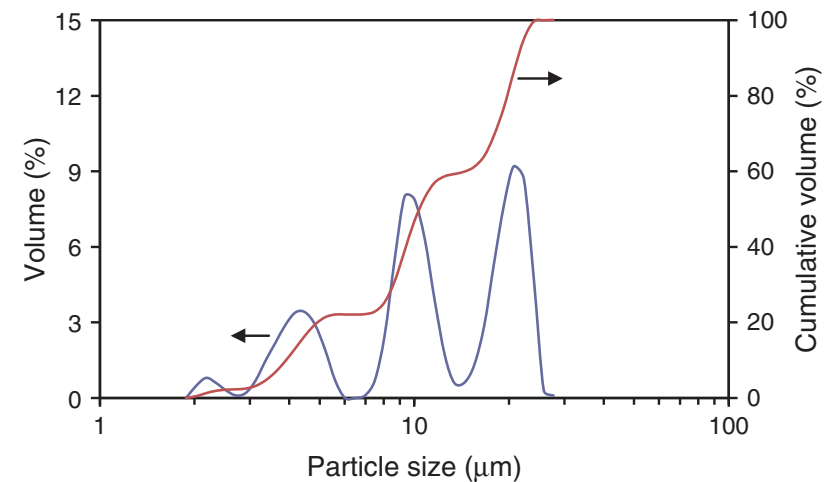

Fig. 4. Particle size distribution of the Sydney dust storm (23 September 2009).
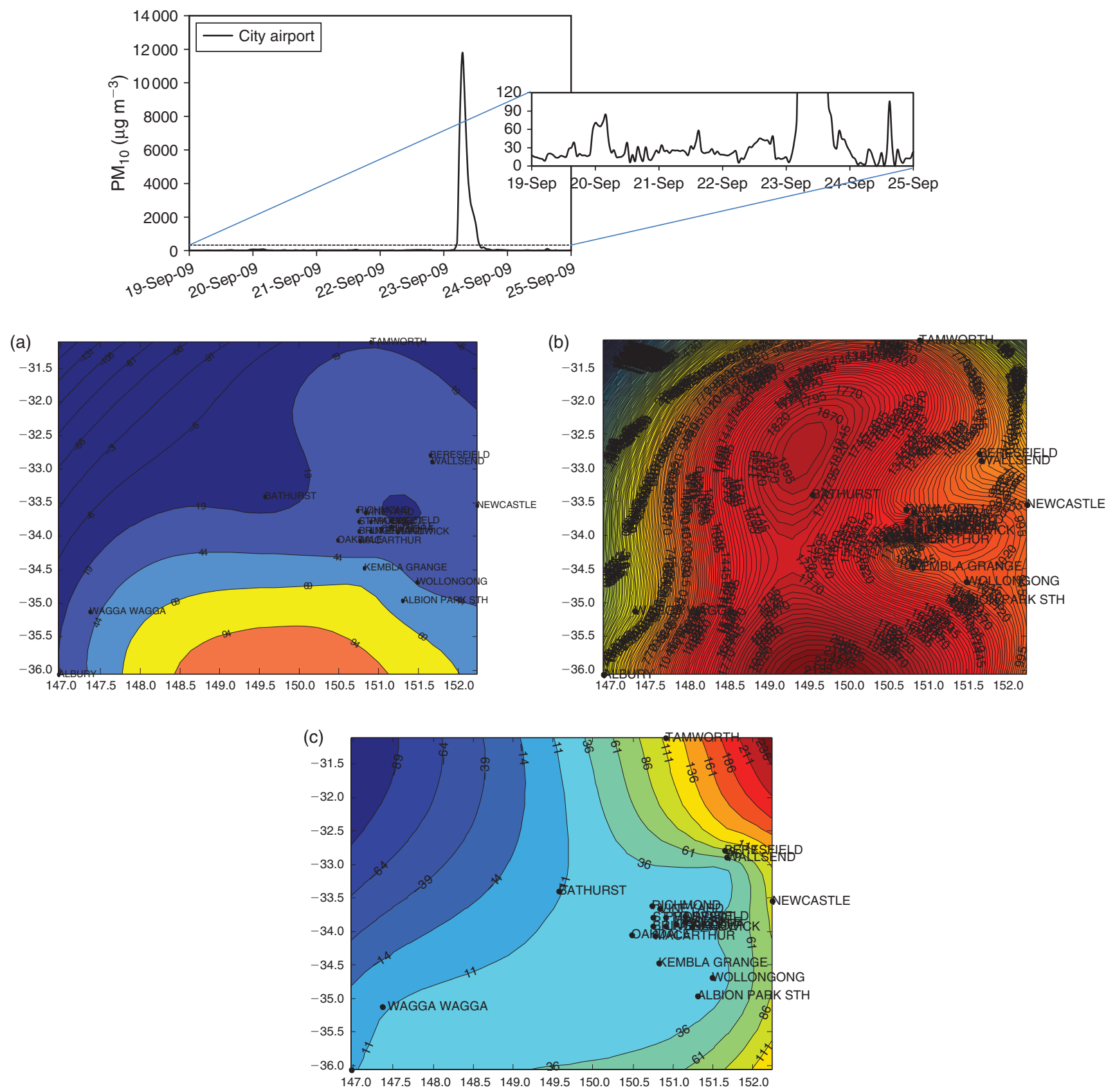

Fig. 3. $\mathrm{PM}_{10}$ (particles measuring $10 \mu \mathrm{m}$ or less) values in Sydney before and during the dust storm in September 2009 (top) and PM 10 distribution in NSW between 1200 and 1500 hours on (a) 22 September, (b) 23 September and (c) 24 September 2009. 
way in addition to its suspected origin, the Lake Eyre Basin, in inner Australia. ${ }^{[38-40]}$

\section{Surface morphology and elemental composition}

SEM and EDX measurements were performed to determine the dust particle size, shape and elemental composition. ${ }^{[41-43]}$ The elemental composition and a backscattered electron image of the dust particles are shown in Fig. 5. The particle size analysis reveals that the dust contains clay and silt particles with diameters up to $12 \mu \mathrm{m}$, which is very similar to the size measured by the particle size analyser. The variation in particle sizes indicates a long range of particle transport. The particles were generally sharp edged and irregular in shape and contained mostly crustal elemental oxides such as $\mathrm{SiO}_{2}, \mathrm{Al}_{2} \mathrm{O}_{3}$ and $\mathrm{Fe}_{2} \mathrm{O}_{3}$. Table 2 shows the distribution of elements in the sampled dust. The ratio of $\mathrm{Al} / \mathrm{Si}$ in the Sydney dust storm was $\sim 0.39$. A similar value was reported by Box et al. in his study on the Sydney dust storm. ${ }^{[38]}$ According to the literature, a ratio of more than 0.3 indicates a desert origin. ${ }^{[44,45]}$ A previous study on the Lake Eyre Basin ${ }^{[39,40,46]}$ supports the hypothesis of the dust origin. This suggests that the particles originated from the inland of Australia and travelled a long distance. Synchrotron X-ray diffraction (XRD) shows a composite mixture of minerals such as quartz, anatase, calcite, orthoclase, alite, hematite, kaolinite, muscovite and montmorillonite (Fig. 6).

\section{Organic analysis}

\section{Thermogravimetric analysis (TGA)}

The TGA method can assist in understanding clay minerals that may gain or drop in weight upon heating. ${ }^{[47,48]}$ The TGA method was applied in a nitrogen atmosphere to investigate the minerals present in the dust (Fig. 7). The analysis shows that the

Table 1. Expected distances travelled by particles of different diameters $^{[37]}$

\begin{tabular}{lcc}
\hline Box model & $\begin{array}{c}\text { Average distance } \\
\text { travelled }(\mathrm{km})\end{array}$ & $\begin{array}{c}\text { Expected particle } \\
\text { diameter }(\mu \mathrm{m})\end{array}$ \\
\hline 1 & 10 & 21.5 \\
2 & 175 & 10.5 \\
3 & 525 & 8.0 \\
4 & 1030 & 6.75 \\
\hline
\end{tabular}

total organic content in the sample was $10.6 \%$. This result was similarly obtained when repeated using the ignition loss method. ${ }^{[23]}$ The dust showed a rapid mass loss of $2.7 \%$ between 50 and $120^{\circ} \mathrm{C}, 2.9 \%$ between 250 and $400{ }^{\circ} \mathrm{C}, 2.5 \%$ between 450 and $550{ }^{\circ} \mathrm{C}$ and $0.33 \%$ between 670 and $700{ }^{\circ} \mathrm{C}$. The mass loss between 250 and $440^{\circ} \mathrm{C}$ corresponded to dehydroxylation of goethite, the mass loss between 450 and $550^{\circ} \mathrm{C}$ corresponded to dehydroxylation of kaolinite and the mass loss between 670 and $700{ }^{\circ} \mathrm{C}$ corresponded to calcium hydroxide being converted into calcium oxide. ${ }^{[4-49]}$ This high organic content in the dust shows that agricultural soils from inland were possibly swept up during the dust storm. DTA displayed two sharp endothermic peaks at 163 and $588^{\circ} \mathrm{C}$, indicating a resemblance to montmorillonite. ${ }^{[47]}$

\section{FTIR analysis}

Qualitative information on the major chemical constituents of the dust samples was obtained by FTIR. The FTIR spectrum of the dust is shown in Fig. 8. The observed bands (400 $4000 \mathrm{~cm}^{-1}$ ) listed in Table 3 were assigned based on the published literature. ${ }^{[50-54]}$ The spectra were different from urban dust spectra where the peaks usually appear at $\sim 2980$ and $2862 \mathrm{~cm}^{-1}$ for alkyl compounds. ${ }^{[55]}$

The peaks for the Sydney dust that appeared at 3698, 3652 and $3627 \mathrm{~cm}^{-1}$ show the hydroxy stretching vibration of alumina. ${ }^{[50,53]}$ Similarly, wide bands appeared in the region $3300-3500 \mathrm{~cm}^{-1}$ and $1651 \mathrm{~cm}^{-1}$, which show $\mathrm{H}-\mathrm{O}-\mathrm{H}$

Table 2. Elemental distribution in dust particle by energy dispersive X-ray diffraction spectroscopy

\begin{tabular}{lrr}
\hline Element & Weight (\%) & Atomic (\%) \\
\hline $\mathrm{C}$ & 3.22 & 5.38 \\
$\mathrm{O}$ & 52.07 & 65.24 \\
$\mathrm{Mg}$ & 1.25 & 1.03 \\
$\mathrm{Al}$ & 9.25 & 6.87 \\
$\mathrm{Si}$ & 24.48 & 17.47 \\
$\mathrm{~S}$ & 0.24 & 0.15 \\
$\mathrm{~K}$ & 2.14 & 1.10 \\
$\mathrm{Ca}$ & 0.63 & 0.32 \\
$\mathrm{Ti}$ & 0.59 & 0.24 \\
$\mathrm{Fe}$ & 6.14 & 2.20 \\
\hline
\end{tabular}

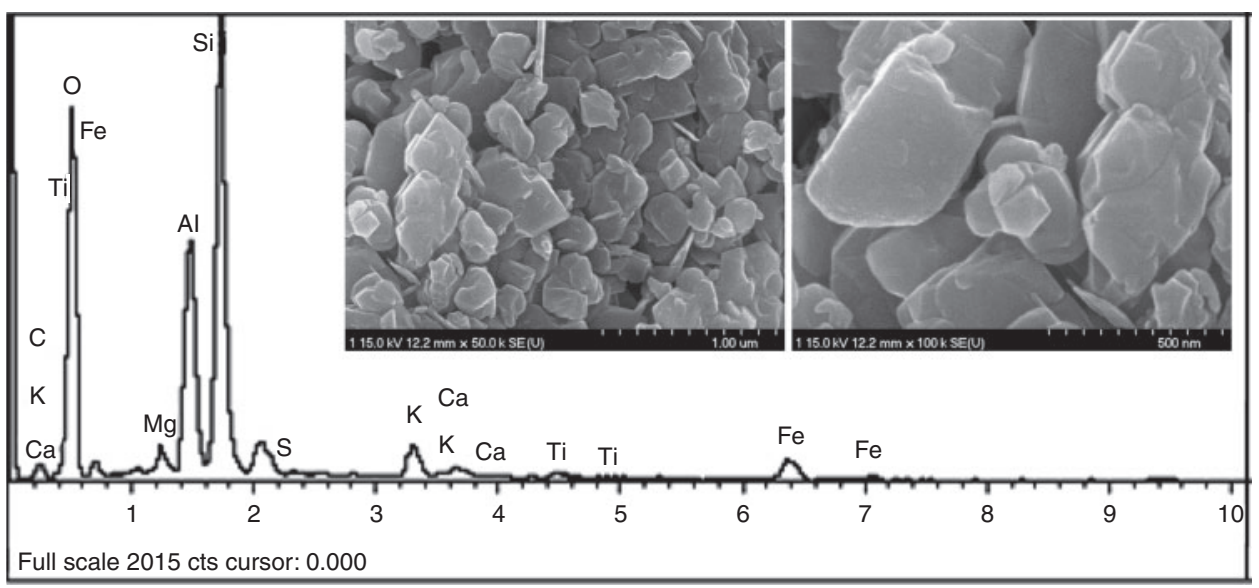

Fig. 5. X-Ray spectrum of the dust particles. 


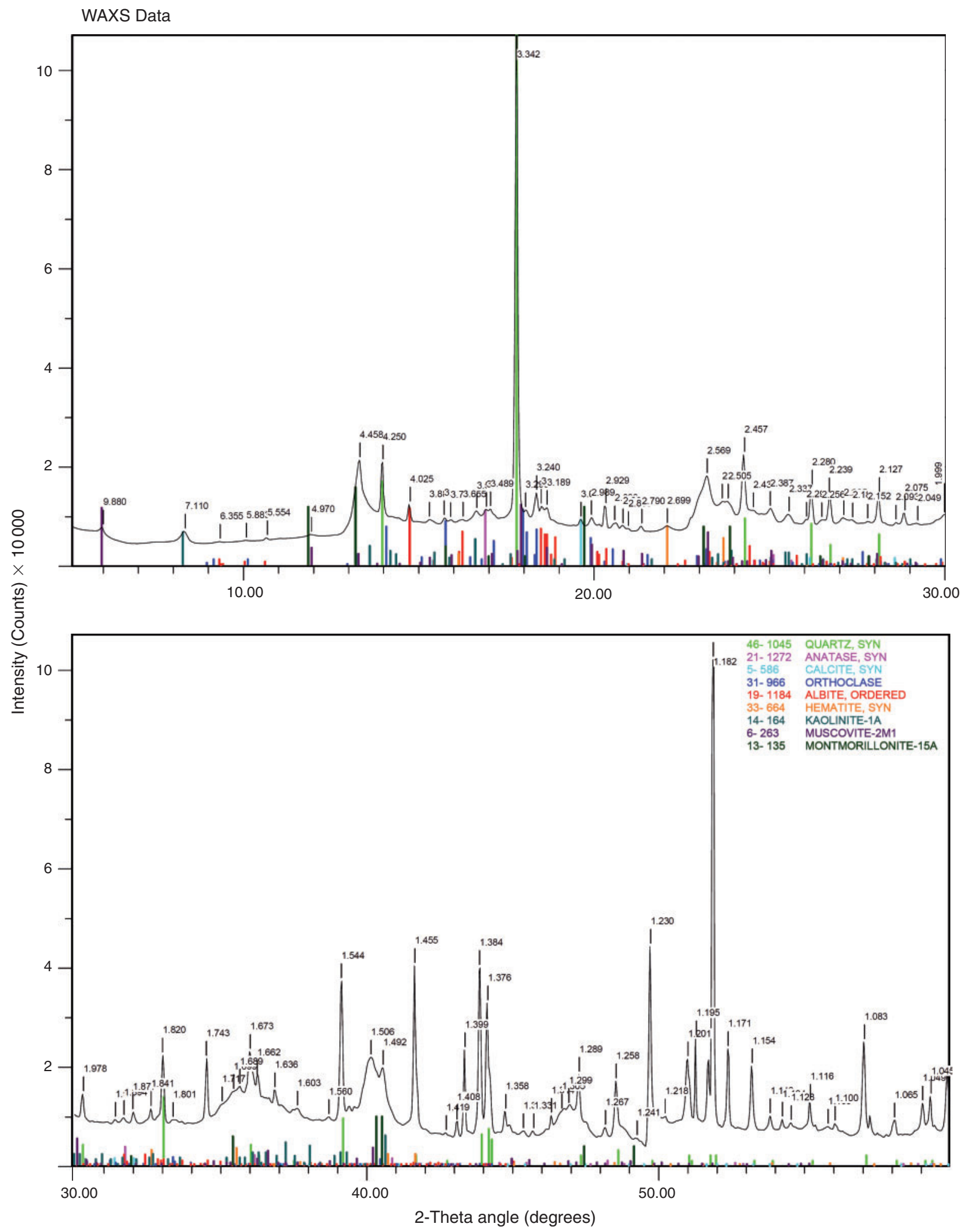

Fig. 6. Synchroton X-ray diffraction pattern of the Sydney dust.

stretching. ${ }^{[53]}$ Bands also appeared at 1170, 1034, 790, 694 and $468 \mathrm{~cm}^{-1}$ showing the presence of $\mathrm{Si}-\mathrm{O}$ and $\mathrm{Si}-\mathrm{O}-\mathrm{Si}$ stretching and at $914 \mathrm{~cm}^{-1}$ showing $\mathrm{Al}-\mathrm{OH}$ deformation and $\mathrm{Fe}-\mathrm{O}$ bonding. Most of the bands such as 3698, 3622, 1033, 914, 791, 694 and $468 \mathrm{~cm}^{-1}$ show the presence of kaolinite. ${ }^{[53]}$ The vibration observed at $914 \mathrm{~cm}^{-1}$ indicates the presence of hematite.
The presence of bands at 3698, 3622, 1034, 914 and $791 \mathrm{~cm}^{-1}$ indicates the possible presence of illite.

Organic functional group bands were also visible in the spectra. The spectra showed three major peaks at 3430, 1720 and $1250 \mathrm{~cm}^{-1}$ due to humic and fulvic substances. ${ }^{[56,57]}$ The peak at $3430 \mathrm{~cm}^{-1}$ was relatively broad showing enriched humic 


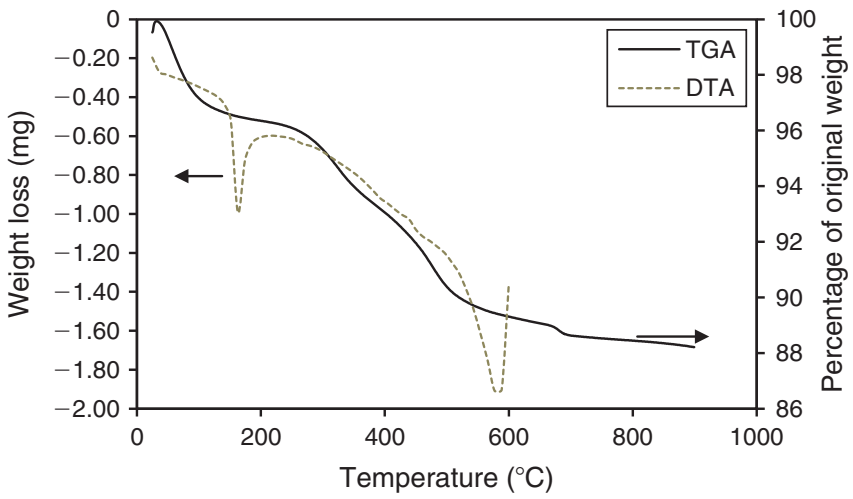

Fig. 7. Thermogravimetric analysis of dust particles

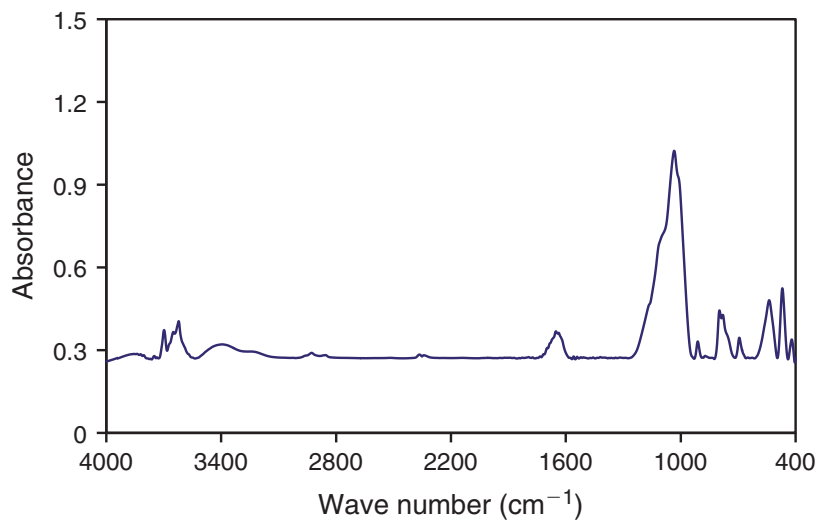

Fig. 8. IR spectra of dust.

Table 3. Fourier-transform infrared spectroscopy bands and their assignment

\begin{tabular}{|c|c|}
\hline Band $\left(\mathrm{cm}^{-1}\right)$ & Assignment \\
\hline 424 & $\mathrm{Si}-\mathrm{O}$ bending ${ }^{[52]}$ \\
\hline 469 & $\mathrm{Si}-\mathrm{O}-\mathrm{Si}, \mathrm{Si}-\mathrm{O}-\mathrm{Fe}$ stretching ${ }^{[50,53,54]}$ \\
\hline 546 & $\mathrm{Si}-\mathrm{O}-\mathrm{Al}$ stretching ${ }^{[53,54]}$ \\
\hline 694 & $\mathrm{Si}-\mathrm{O}$ stretching., $\mathrm{Si}-\mathrm{O}-\mathrm{Al}$ stretching ${ }^{[53]}$ \\
\hline 791 & $\mathrm{OH}$ deformation linked to $\mathrm{Al}$ and $\mathrm{Mg}^{[53]}$ \\
\hline 800 & $\mathrm{Si}-\mathrm{O}$ stretching, $\mathrm{Si}-\mathrm{O}-\mathrm{Al}$ stretching ${ }^{[53]}$ \\
\hline 914 & $\mathrm{Al}-\mathrm{OH}$ deformation ${ }^{[51,53]}$ \\
\hline 1034 & $\mathrm{Si}-\mathrm{O}-\mathrm{Si}, \mathrm{Si}-\mathrm{O}$ stretching ${ }^{[53]}$ \\
\hline 1170 & $\mathrm{Si}-\mathrm{O}$ stretching ${ }^{[52]}$ \\
\hline 1250 & Fulvic, humic band ${ }^{[56,57]}$ \\
\hline 1651 & $\begin{array}{l}\mathrm{H}-\mathrm{O}-\mathrm{H} \text { stretching }{ }^{[53]} \mathrm{C}=\mathrm{O} \text { stretching of humics, } \\
\text { hydrogen-bonded conjugated to carbonyl } \\
\text { of humics }{ }^{[65]}\end{array}$ \\
\hline 1720 & Fulvic, humic band ${ }^{[56,57]}$ \\
\hline $3300-3500$ & $\mathrm{H}-\mathrm{O}-\mathrm{H}$ stretching ${ }^{[53]}$ \\
\hline 3430 & Fulvic, humic band ${ }^{[56,57]}$ \\
\hline 3622 & $\mathrm{Al}-\mathrm{Si}$ lattice vibration. $\mathrm{Al}-\mathrm{OH}^{[51,53,54]}$ \\
\hline 3650 & Al-Si lattice vibration, $\mathrm{Al}-\mathrm{OH}$ stretching ${ }^{[51,54]}$ \\
\hline 3698 & $\mathrm{Al}-\mathrm{O}-\mathrm{H}$ stretching ${ }^{[51,53,54]}$ \\
\hline
\end{tabular}

and fulvic substances in the dust. These peaks support the results of gravimetric analysis.

\section{Fluorescence analysis}

Fluorescence spectroscopy has been applied extensively in water and wastewater analysis to characterise organic matter

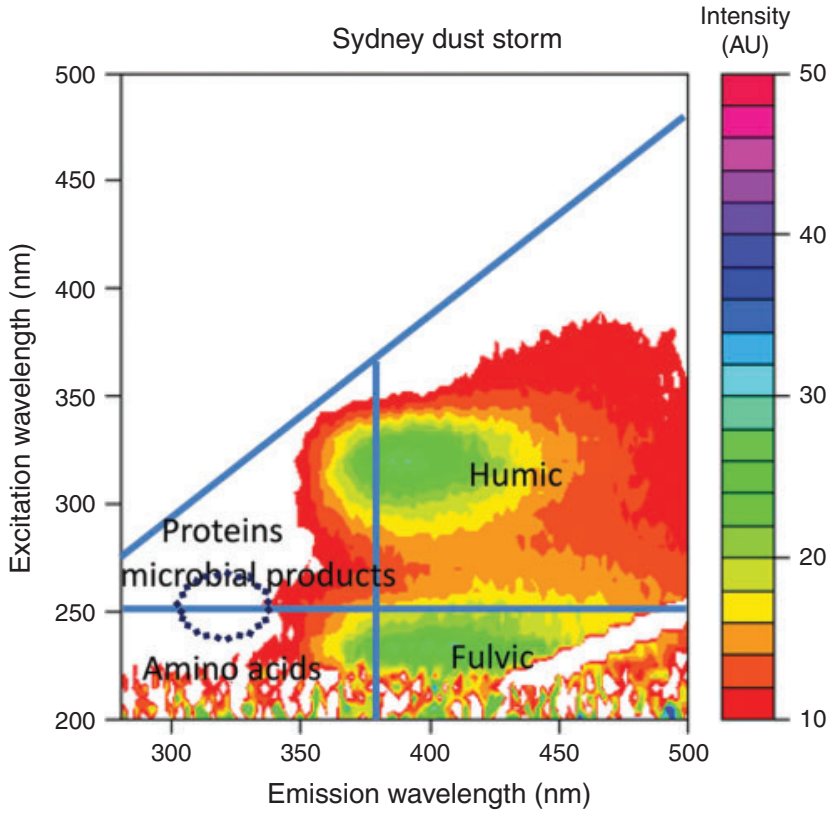

Fig. 9. Organic substances present in the dust storm.

and its origin. ${ }^{[58,59]}$ However, interest in the application of fluorescence to atmospheric PM has only started relatively recently. ${ }^{[60,61]}$ Its high sensitivity and its specificity to organics such as amino acids, aromatic amino acids, dipicolinic acid, cytochrome, etc., has made the technique valuable for quantifying the presence of bacteria and viruses. Predominant fluorophores, with excitation between 245 and $300 \mathrm{~nm}$ and emission between 330 and $340 \mathrm{~nm}$, are tryptophan like molecules that are found in both bacteria and viruses. ${ }^{[62,63]}$

Fig. 9 shows an extract of the fluorescence spectra of the Sydney dust. The spectra is broadly categorised into four different regions to understand the nature and source of organics. ${ }^{[58]}$ These major organic regions are amino acids, fulvics, humics, and proteins and microbial products. The spectra displayed strong bands in the humic and fulvic regions indicating the presence of a large amount of humic and fulvic substances in the dust particles. This also provides additional evidence that a large amount of agricultural soil was caught up in the Sydney dust. According to Pan et al. ${ }^{[60]}$ the fluorescence region, with excitation between 245 and $265 \mathrm{~nm}$ and emission between 330 and $350 \mathrm{~nm}$, shown by the dotted circle in Fig. 9, is a biohazardous indicator region. We did not observe any prominent peak in this region. The appearance of a peak in the protein region is possibly due to the presence of agricultural organics in the dust. This result shows that it was unlikely that the Sydney dust storm carried biohazardous substances.

\section{MWD analysis}

High pressure size exclusion chromatography (HPSEC) has often been applied to the fractionation of macro as well as micromolecules in soils and sediments to characterise their nature. ${ }^{[64,65]}$ Two detectors commonly used in identifying these molecules are UV and fluorescence. The fluorescence detector (excitation at $250 \mathrm{~nm}$, emission at $340 \mathrm{~nm}$ ) is suited for specific organic material because it can resolve different fluorophores within organic materials. ${ }^{[66]}$ Ultraviolet light of wavelength $254\left(\mathrm{UV}_{254}\right)$ is widely applied to identify aromatic organics. 

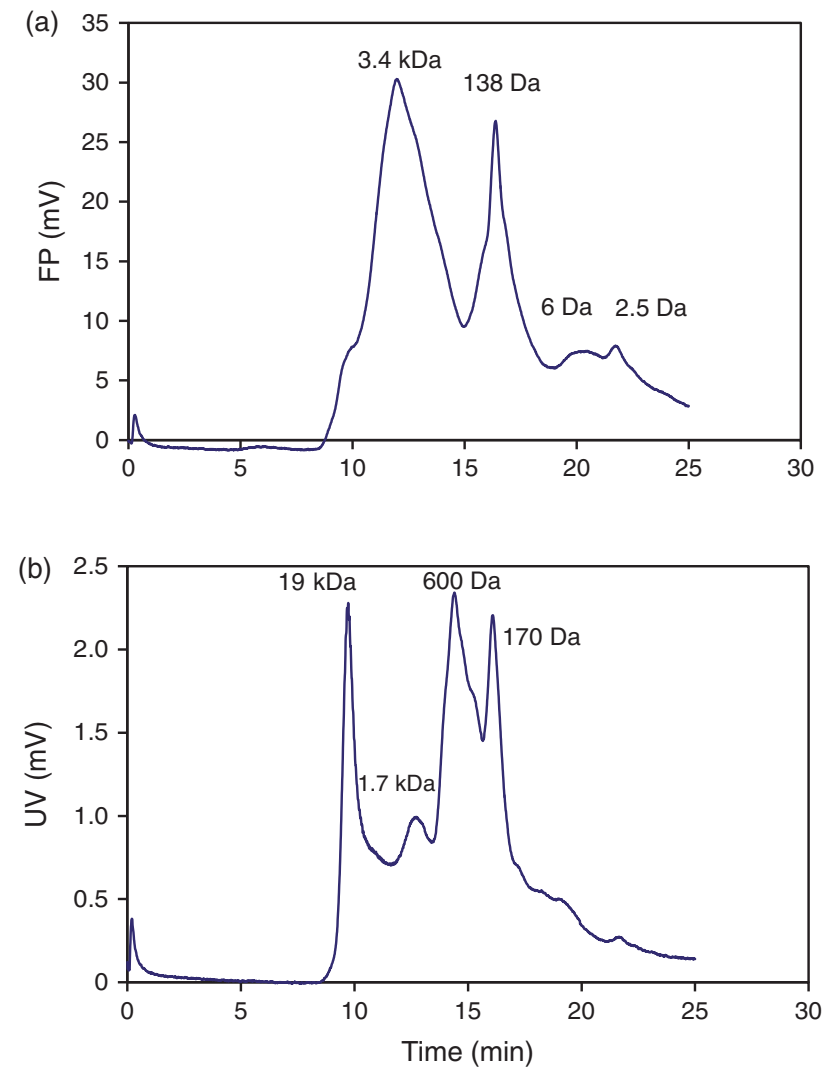

Fig. 10. Characterisation of Sydney dust storm organics using high pressure size exclusion chromatography with (a) a fluorescence detector and (b) a UV detector.

These techniques were applied to investigate the organic molecular sizes present in the Sydney dust.

Fig. 10a, b shows the chromatogram obtained using HPSEC with fluorescence and UV detectors. Fluorescence produced a large broad peak that covered a broad range of organics ( $1 \mathrm{Da}$ to $20 \mathrm{kDa}$ ), especially humic and fulvic types. The second and third peaks were mainly due to low molecular weight neutral and acidic organics. The UV detector produced a few distinct peaks at $19,1.7$ and less than $1 \mathrm{kDa}$. The first and second peaks are associated with humic and fulvic type organics. The peaks below $1 \mathrm{kDa}$ are mostly low molecular weight acids or neutrals. Both spectra indicated that the dust contained organics less than $20 \mathrm{kDa}$ in weight. This result indicated that humic and fulvic organics were predominant in the dust. Proteins and biomolecules are usually $>30 \mathrm{kDa}$ in size.$^{[67]}$ The absence of larger size organics $(>30 \mathrm{kDa})$ in the Sydney dust indicated that the presence of biohazardous substances was unlikely. Organic substances less than $20 \mathrm{kDa}$ in molecular weight include carbohydrates, humic substances and lower molecular weight organic substances. ${ }^{[68,69]}$

\section{Conclusions}

Dust particles were collected during the Sydney dust storm on 23 September 2009 in Sydney, Australia and analysed for mineralogical and organic contents. The particle size distribution in the dust was multimodal $(0.6,4.5,9.3$ and $20 \mu \mathrm{m})$, which indicated the long range of the dust transport before it reached Sydney. The mineralogical study showed that the particles contained $\mathrm{Si}, \mathrm{Al}$ and $\mathrm{Fe}$ in oxide form in which the $\mathrm{Al} / \mathrm{Si}$ ratio was 0.39 . The high organic content and $\mathrm{Al} / \mathrm{Si}$ ratio indicated that the particles originated from agricultural land as well as desert. The organic content in the dust was $10.6 \%$ and reflected that the dust also contained top soil from the inland of NSW. The FTIR and XRD analyses showed different clays and clay type soils in the dust. The fluorescence spectroscopy and SEC showed humic-type organic substances were present in the dust.

\section{Acknowledgements}

The authors acknowledge Nigel Kirby at the SAXS WAXS beam line, Australian Synchrotron for help with WAXS measurement and Mark Raven at CSIRO Land and Water, Adelaide, for the assistance with the analysis of WAXS data.

\section{References}

[1] Y. Ben-Ami, I. Koren, Y. Rudich, P. Artaxo, S. Martin, T. M. O. Andreae, Transport of Saharan dust from the Bodele Depression to the Amazon Basin: a case study. Atmos. Chem. Phys. Discuss. 2010, 10, 4345. doi:10.5194/ACPD-10-4345-2010

[2] T. H. Lin, Long-range transport of yellow sand to Taiwan in spring 2000: observed evidence and simulation. Atmos. Environ. 2001, 35, 5873. doi:10.1016/S1352-2310(01)00392-2

[3] C. Schultz, Determining the trigger of East Asian dust storms. Eos Trans. $A G U$ 2011, 92, 264. doi:10.1029/2011EO310006

[4] C. A. Pope III, D. W. Dockery, Epidemiology of particle effects, in Air Pollution and Health (Eds S. T. Holgate, J. M. Samet, H. S. Koren, R. L. Maynard),1999, pp. 673-705 (Academic Press: London).

[5] C. A. Pope III, R. T. Burnett, M. J. Thun, E. E. Calle, D. Krewski, $\mathrm{K}$. Ito, Lung cancer, cardiopulmonary mortality, and longterm exposure to fine particulate air pollution. J. Aa. Med. Assoc. 2002, 287, 1132. doi:10.1001/JAMA.287.9.1132

[6] J. M. Samet, F. Dominici, F. C. Curriero, I. Coursac, S. L. Zeger, Fine particulate air pollution and mortality in 20 US cities, 1987-1994. New Engl. J. Med. 2000, 343, 1742. doi:10.1056/ NEJM200012143432401

[7] Y. C. Lei, C. C. Chan, P. Y. Wang, C. T. Lee, T. J. Cheng, Effects of Asian dust event particles on inflammation markers in peripheral blood and bronchoalveolar lavage in pulmonary hypertensive rats. Environ. Res. 2004, 95, 71. doi:10.1016/S0013-9351(03)00136-1

[8] G. Sterk, A. Stein, Mapping wind-blown mass transport by modeling variability in space and time. Soil Sci. Soc. Am. J. 1997, 61, 232. doi:10.2136/SSSAJ1997.03615995006100010032X

[9] R. Stefanski, M. V. K. Shivakumar, Impacts of sand ad dust storms on agriculture and potential agricultural applications of a SDSWS. IOP Conf. Ser. - Earth Environ. Sci. 2009, 7, 012016. doi:10.1088/17551307/7/1/012016

[10] K. Michels, M. V. K. Sivakumar, B. E. Allison, Wind erosion millet production. Agric. For. Meteorol. 1993, 67, 65. doi:10.1016/01681923(93)90050-R

[11] K. Michels, D. V. Armbrust, B. E. Allison, M. V. K. Sivakumar, Wind and windblown sand damage to pearl millet. Agron. J. 1995, 87, 620. doi:10.2134/AGRONJ1995.00021962008700040003X

[12] D. W. Fryreat, Survival and growth of cotton plants damaged by windblown sand. Agron. J. 1971, 63, 638. doi:10.2134/ AGRONJ1971.00021962006300040038X

[13] Y. Shao, M. Raupach, J. F. Leys, A model for predicting aeolian sand drift and dust entrainment on scales from paddock to region. Aust. J. Soil Res. 1996, 34, 309. doi:10.1071/SR9960309

[14] R. Sabouri, M. Afkhami, A. Zarasvandi, M. Khodadadi, Correlation analysis of dust concentration and water quality indicators. Int. J. Environ. Sci. Dev. 2011, 2, 91 .

[15] S. A. Akrasi, The assessment of suspended sediment inputs to Volta Lake. Lakes Reservoirs: Res. Manage. 2005, 10, 179. doi:10.1111/ J.1440-1770.2005.00272.X

[16] H. Breuning-Madsen, G. Lyngsie, T. W. Awadzi, Sediment and nutrient deposition in Lake Volta in Ghana due to Harmattan dust. Catena 2012, 92, 99. doi:10.1016/J.CATENA.2011.11.018 
[17] R. P. Singh, A. K. Prasad, V. K. Kayetha, M. Kafatos, Enhancement of oceanic parameters associated with dust storms using satellite data. J. Geophys. Res. 2008, 113, C11008. doi:10.1029/2008JC004815

[18] N. Lim, C. I. Munday, G. E. Allison, T. O’Loingsigh, P. De Deckker, N. Tapper, Microbiological and meteorological analysis of two Australian dust storms in April 2009. Sci. Total Environ. 2011, 412-413, 223. doi:10.1016/J.SCITOTENV.2011.10.030

[19] Dust readings off the chart 2009 (Department of Environment, Climate Change and Water). Available at http://www.environment.nsw.gov. au/media/DecMedia09092301.htm [verified 19 November 2012].

[20] P. R. Tozer, The cost of red dawn to the NSW economy, in 56th Conference on Australian Agricultural and Resource Economics Society, Fremantle, WA, 7-10 February 2012 (Australian Agricultural and Resource Economics Society). Available at http://www.aares.org. au/aares/documents/2012ACPapers/Tozer.pdf [verified 19 November 2012].

[21] National Ambient Air Quality Standards (NAAQS) 2008 (US EPA). Available at http://www.epa.gov/air/criteria.html [verified 19 November 2012]

[22] L. Paoletti, B. De Bernardis, D. Diociaiuti, Physico-chemical characterization of the inhalable particulate matter $\left(\mathrm{PM}_{10}\right)$ in an urban area: an analysis of the seasonal trend Sci. Total Environ. 2002, 292, 265. doi:10.1016/S0048-9697(01)01134-2

[23] M. A. Hossain, H. Furumai, F. Nakajima, R. K. Aryal, Heavy metals speciation in sediment accumulated within an infiltration facility and evaluation of metal retention properties of underlying soil. Water Sci. Technol. 2007, 56, 81. doi:10.2166/WST.2007.746

[24] K. Donaldson, W. MacNee, Potential mechanisms of adverse pulmonary and cardiovascular effects of particulate air pollution $\left(\mathrm{PM}_{10}\right)$. Int J. Hyg. Environ. Health 2001, 203, 411. doi:10.1078/1438-463900059

[25] H. Kan, B. Chen, Air pollution and daily mortality in Shanghai: a timeseries study. Arch. Environ. Health 2003, 58, 360

[26] M. S. Goldberg, R. T. Burnett, J. F. Yale, M. F. Valois, J. R. Brook, Association between ambient air pollution and daily mortality among persons with diabetes and cardiovascular disease. Environ. Res. 2006, 100, 255. doi:10.1016/J.ENVRES.2005.04.007

[27] B. D. Ostro, S. Hurley, M. J. Lipsett, Air pollution and daily mortality in the Coachella valley, California: a study of $\mathrm{PM}_{10}$ dominated by coarse particles Environ. Res. A 1999, 81, 231. doi:10.1006/ENRS. 1999.3978

[28] J. H. Seinfeld, Atmospheric Chemistry and Physics of Air Pollution 1986 (Wiley: New York).

[29] G. Toscano, I. Moret, A. Gambaro, C. Barbante, G. Capodaglio, Distribution and seasonal variability of trace elements in atmospheric particulate in the Venice Lagoon Chemosphere 2011, 85, 1518 doi:10.1016/J.CHEMOSPHERE.2011.09.045

[30] Hospital Quarterly: Performance of NSW Public Hospitals, October to December 2010. 2011, vol. 1, issue 3 (Bureau of Health Information: Sydney).

[31] J. F. Leys, S. K. Heidenreich, C. L. Strong, G. H. McTainsh, S. Quigley, $\mathrm{PM}_{10}$ concentration and mass transport during 'Red Dawn’ Sydney September 2009. Aeolin Research 2011, 3, 327. doi:10.1016/J.AEOLIA.2011.06.003

[32] V. S. Bashurova, K. P. Koutzenogil, A. Y. Pusep, N. V. Shokhirev, Determination of atmospheric aerosol size distribution functions from screen diffusion battery data: mathematical aspects. J. Aerosol Sci. 1991, 22, 373. doi:10.1016/S0021-8502(05)80014-X

[33] A. A. Karanasiou, I. E. Sitaras, P. A. Siskos, K. Eleftheriadis, Size distribution and sources of trace metals and $n$-alkane in the Athens urban aerosol during summer Atmos. Environ. 2007, 41, 2368. doi:10.1016/J.ATMOSENV.2006.11.006

[34] A. Waheed, X. Li, M. Tan, L. Bao, J. Liu, Y. Zhang, G. Zhang, Y. Li, Size distribution and sources of trace metals in ultrafine/fine/coarse airborne particles in the atmosphere of Shanghai. Aerosol Sci. Technol. 2011, 45, 163. doi:10.1080/02786826.2010.528079

[35] R. Kumar, S. Shrivastava, K. M. Kumari, Characteristics of aerosols over suburban and urban site of semiarid region in India: seasonal and spatial variations. Aerosol Air Qual. Res. 2007, 7, 531.
[36] E. R. Jayaratne, G. R. Johnson, P. McGarry, H. C. Cheung, L. Morawska, Characteristics of airborne ultrafine and coarse particles during the Australian dust storm of 23 September 2009. Atmos. Environ. 2011, 45, 3996. doi:10.1016/J.ATMOSENV.2011.04.059

[37] A. W. Knight, G. H. McTainsh, R. W. Simpson, Sediment loads in Australian dust storm: implications for present and past dust processes. Catena 1995, 24, 195. doi:10.1016/0341-8162(95)00026-O

[38] M. A. Box, M. Radhi, G. P. Box, The great Sydney dust event: size resolved chemical composition and comparison. IOP Conf. Series: Earth and Environmental Science 2010, 11, 012015. doi:10.1088/ 1755-1315/11/1/012015

[39] M. Radhi, M. A. Box, G. P. Box, D. D. Cohen, Size-resolved chemical composition of the September 2009 Sydney dust storm. Air Qual. Climate Change 2010, 44, 25.

[40] M. Radhi, M. A. Box, R. M. Mitchell, D. D. Cohen, E. Stelcer, M. D. Keywood, Size-resolved mass and chemical properties of dust aerosols from Australia's Lake Eyre Basin Atmos. Environ. 2010, 44, 3519. doi:10.1016/J.ATMOSENV.2010.06.016

[41] T. Kyotani, Characterization of individual silicon-poor particles in atmospheric aerosols by SEM-EDX and application to Kosa particle identification. Spectrosc. Lett. 2005, 38, 365. doi:10.1081/ SL-200058718

[42] Z. Shen, X. Li, J. Cao, C. Sandrine, Y. Wang, X. Zhang, Characteristics of clay minerals in Asian dust and their environmental significance. China Particuology 2005, 3, 260. doi:10.1016/S1672-2515(07) 60198-5

[43] Z. Shi, L. Shao, T. P. Jones, S. Lu, Microscopy and mineralogy of airborne particles collected during severe dust storm episodes in Beijing, China. J. Geophys. Res. 2005, 110, D01303. doi:10.1029/ 2004JD005073

[44] S. Guerzoni, E. Molinaroli, R. Chester, Saharan dust inputs to the western Mediterranean Sea: Depositional patterns, geochemistry and sedimentological implications Deep Sea Res. Part II Top. Stud. Oceanogr. 1997, 44, 631. doi:10.1016/S0967-0645(96)00096-3

[45] A. Blanco, F. D. Tomasi, E. Filippo, D. Manno, M. R. Perrone, A. Serra, A. M. Tafuro, A. Tepore, Characterization of African dust over southern Italy. Atmos. Chem. Phys. Discuss. 2003, 3, 4633. doi:10.5194/ACPD-3-4633-2003

[46] M. Radhi, M. A. Box, G. P. Box, M. D. Keywood, D. D. Cohen, E. Stelcer, R. M. Mitchell, Size-resolved chemical composition of Australian dust aerosol during winter Environ. Chem. 2011, 8, 248. doi:10.1071/EN10134

[47] R. Mielenz, N. C. Schieltz, M. E. King, Thermogravimetric analysis of clay and clay-like minerals, in Clays and Clay Minerals: Proceeding of 2nd National Conference on Clay and Clay Minerals, Columbia, MO, 15-17 October 1953 (Eds N. Plummer, A. Swineford) 1953 p. 285 (National Academy of Sciences).

[48] P. K. Weissenborn, J. G. Dunn, L. J. Warren, Quantitative thermogravimetric analysis of haematite, goethite and kaolinite in Western Australian iron ores. Thermochim. Acta 1994, 239, 147. doi:10.1016/ 0040-6031(94)87063-2

[49] A. Chaisena, K. Rangsriwatananon, Effects of thermal and acid treatments on some physico-chemical properties of Lampang diatomite. Suranaree J. Sci Technol 2004, 11, 289.

[50] T. T. Nguyen, L. J. Janik, M. Raupach, Diffuse reflectance infrared fourier transform (DRIFT) spectroscopy in soil studies. Aust. J. Soil Res. 1991, 29, 49. doi:10.1071/SR9910049

[51] J. Bertaux, F. Frohilch, P. Ildefonse, Multicomponent analysis of FTIR spectra; quantification of amorphous and crystallized mineral phases in synthetic and natural sediments. J. Sediment. Res. 1998, 68, 440. doi:10.2110/JSR.68.440

[52] T. Bakharev, Resistance of geopolymer materials to acid attack. Cement Concr. Res. 2005, 35, 658. doi:10.1016/J.CEMCONRES. 2004.06.005

[53] P. S. Nayak, B. K. Singh, Instrumental characterisation of clay by XRF, XRD and FTIR. Bull. Mater. Sci. 2007, 30, 235. doi:10.1007/ S12034-007-0042-5

[54] B. J. Saikia, G. Parthasarathy, Fourier transform infrared spectroscopic characterisation of kaolinite from Assam and Meghalaya, 
Northeastern India. J. Mod. Phys. 2010, 1, 206. doi:10.4236/JMP. 2010.14031

[55] J. Zhao, P. Peng, J. Song, S. Ma, G. Sheng, J. Fu, Characterisation of macromolecular organic matter in atmospheric dust from Guangzhou, China Atmos. Environ. 2011, 45, 5612. doi:10.1016/J.ATMOSENV. 2011.04.039

[56] D. Gondar, R. Lopez, S. Siol, J. M. Antelo, F. Arce, Characterisation and acid-base properties of fulvic and humic acids isolated from two horizons of an ambrotropic peak bog. Geoderma 2005, 126, 367. doi:10.1016/J.GEODERMA.2004.10.006

[57] F. Sakellariadou, Spectroscopic studies of humic acids from surface sediment samples collected across the Agean sea. Medit. Mar. Sci. 2006, 7, 11.

[58] W. Chen, P. Westerhoff, J. Leenheer, K. Booksh, Fluorescence excitation-emission matrix regional integration to quantify spectra for dissolved organic matter. Environ. Sci. Technol. 2003, 37, 5701. doi:10.1021/ES034354C

[59] R. Aryal, J. Lebegue, S. Vigneswaran, J. Kandasamy, A. Grasmick, Identification and characterisation of biofilm formed on membrane bio-reactor. Separ. Purif. Technol. 2009, 67, 86. doi:10.1016/J.SEP PUR.2009.03.031

[60] Y. L. Pan, P. J. Cobler, S. C. Rhodes, J. Halverson, R. K. Chang, Separating hazardous aerosols from ambient aerosols: role of fluorescence-spectral determination, aerodynamic deflector and pulse aerodynamic localizer (PAL). Proc. SPIE 2005, 5990, 59900Y-1.

[61] K. Davitt, Y. K. Song, W. R. Patterson, A. V. Nurmikko, Y. L. Pan, R. K. Chang, J. Han, M. Gherasimova, P. Cobler, P. Butler, V. Palermo, Spectroscopic sorting of aerosols by compact sensor employing UV LEDs. Aerosol Sci. Technol. 2006, 40, 1047. doi: $10.1080 / 02786820600936774$

[62] A. Alimova, A. Katz, R. Podder, G. Minko, H. Wei, Virus particles monitored by fluorescence spectroscopy: a potential detection assay for macromolecular assembly. Photochem. Photobiol. 2004, 80, 41. doi:10.1562/2004-02-11-RA-080.1

[63] A. Shahzad, G. Kohler, M. Knapp, E. Gaubitzer, M. Puchinger, M. Edetsberger, Emerging applications of fluorescence spectroscopy in medical microbiology field. J. Transl. Med. 2009, 7, 99. doi:10.1186/1479-5876-7-99

[64] S. Mori, M. Kato, High-performance aqueous size-exclusion chromatography using diol-bonded porous glass packing materials. Retention behavior of some proteins. J. Liq. Chromatogr. 1987, 10, 3113. doi:10.1080/01483918708068301

[65] V. D’Orazio, N. Senesi, Spectroscopic properties of humic acids isolated from rhizosphere and bulk soil compartments and fractionated by size exclusion chromatography. Soil Biol. Biochem. 2009, $41,1776$.

[66] S. Nagao, T. Matsunaga, Y. Suzuki, T. Ueno, H. Amano, Characteristics of humic substances in the Kuji River waters as determined by high-performance size exclusion chromatography with fluorescence detection. Water Res. 2003, 37, 4159. doi:10.1016/S0043-1354(03) 00377-4

[67] D. Niemeyer, A. Becker, The molecular weight distribution of succinoglycan produced by sinorhizobium meliloti is influenced by specific tyrosine phosphorylation and ATPase activity of the cytoplasmic domain of the exop protein. J. Bacteriol. 2001, 183, 5163. doi:10.1128/JB.183.17.5163-5170.2001

[68] N. Azema, M. F. Pouet, C. Berho, O. Thomas, Wastewater suspended solids study by optical methods. Colloid Surf. A. 2002, 204, 131. doi:10.1016/S0927-7757(02)00006-7

[69] J. R. Lead, K. J. Wilkinson, Environmental Colloids and Particles: Behaviour, Structure and Characterisation (Eds K. J. Wilkinson, J. R. Lead) 2006, vol. 10 (Wiley: Chichester, UK). 